\title{
EXCURSION TO THE NEW RAILWAY BETWEEN GRAYS AND UPMINSTER, ESSEX.
}

JUNE $27 \mathrm{TH}, 189 \mathrm{I}$.

\author{
Director: T. V. HoLmes, F.G.S. \\ (Report by The DiRector.)
}

[Nore.-Some Notes on the Geology of this Railway were read by Mr. Holmes at the Meeting on Friday, April $3^{\text {rd, }}$ 189r. Those Notes are incorporated with the present Report.]

This line, which connects that from London to Tilbury and Southend with the recently opened railway from Barking to Upminster, Langdon Hills, and Pitsea, is about seven miles long. The most interesting portion of the line, to a geologist, is that south of the Mardyke (see Map, fig. I). South of the road between Grays Thurrock Station and West Thurrock, the railway runs on an embankment as far as its junction with the line from London to Tilbury. North of the road, however, the embankment is soon replaced by a cutting, and at the point $(a)$ on the map, the junction of Chalk with the Thames Valley Gravel becomes visible. At this spot the 50 feet contour line crosses the railway. Between $(a)$ and $(c)$, a distance of nearly half a mile, there is a rather deep cutting in the Chalk, and at $(c)$ may be seen the junction of the Chalk with gravel, sand and loam lying at a higher level than that at $(a)$. Between $(c)$ and Back Lane, Chalk appears here and there at the base of this gravel, but north of Back Lane the gravel rests upon the Thanet Sand, the junction between the Chalk and Thanet Sand being visible close to, and on the northern side of, Back Lane Bridge. The junction between the Thanet Sand and the Woolwich Beds as well as the Woolwich Beds themselves are hidden under the alluvium of the Mardyke; while the London Clay appears in the cutting on the northern side of the valley close to the road from Aveley to Stifford, capped by a little gravel.

North of this road from Aveley to Stifford the course of the line is on a plateau consisting of London Clay capped by gravel, sand, or loam, and having an average height of from 60 to $70 \mathrm{ft}$. above Ordnance Datum, a height which agrees precisely with that between the point $(c)$ and the southern edge of the Mardyke Valley. East of Cranham Hall, and thence to Upminster Station there is an embankment which rests upon London Clay. In short, north of the Mardyke, the sections visible confirm the general accuracy of the Geological Survey Map, and consist mainly of gravel as far as a point east of Stubbers, while thence to Cranham Hall loamy beds are seen.

Returning to the southern side of the Mardyke Valley, it may be well to add a few notes on various points not well seen on the excursion. At the junction between the Chalk and the Thames 
Valley Gravel at $(a)$ perhaps the most interesting object seen was a pipe, which, taking a somewhat diagonal course from the surface downwards, presented in the cutting the appearance of a mass of
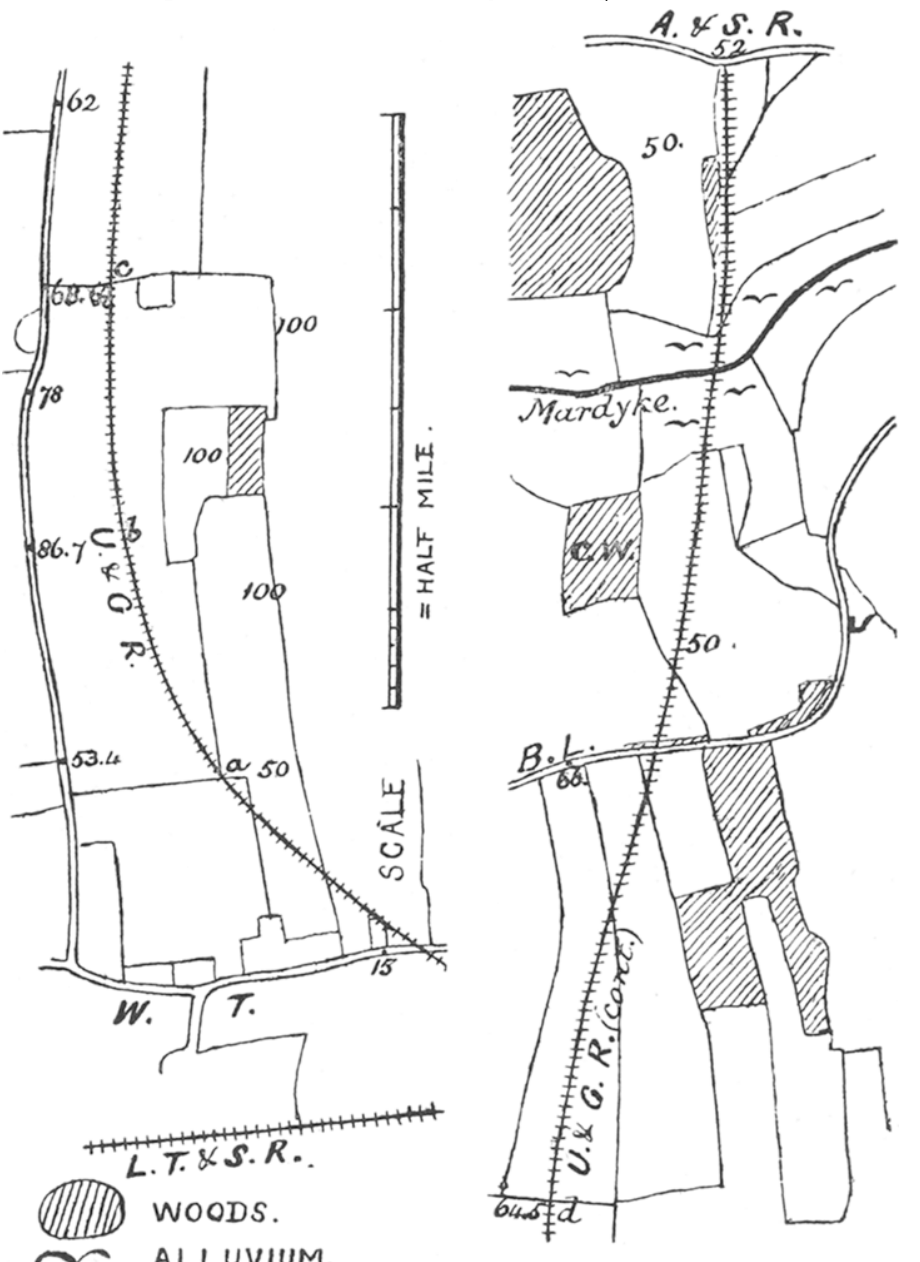

Fig. I.-Sketch MaP of Grays and Upminster Railway.- $T$. $V$. Holmes.

L.T. \& S.R.-London, Tilbury and Southend Railway. $U$. E G.R.-Upminster and Grays Railway.

W.T-West Thurrock.

A. \& S.R.-Aveley and Stifford Road. C.W.-Combe Wood.

gravel entirely surrounded by solid Chalk. Other pipes similar to it were seen in the Chalk cutting between $(a)$ and $(c)$. Their 
existence seems worth recording, because, though common in certain chalk pits, as in that at Caterham Junction, pipes of this kind cannot be seen in perhaps nine quarries out of ten.

About half-way between this point $(c)$ and Back Lane, a cutting through this higher level gravel becomes deep enough to show the extreme irregularity of its junction with the underlying Chalk, gravel and chalk being so mixed together as to suggest at first sight the agency of something beyond mere carbonated water. But inspection of the junction between the Chalk and the various overlying deposits in the huge chalk pits of the district inclines one to believe that after all there is nothing shown which is necessarily beyond the power of the ordinary pipemaking agency. At the same time, it is quite possible, and by no means improbable, that the action of river-ice may have assisted in producing some of these peculiarities; indeed, in old river deposits like these gravels, it must necessarily have produced some effects, whether now distinguishable by us or not. It is, moreover,

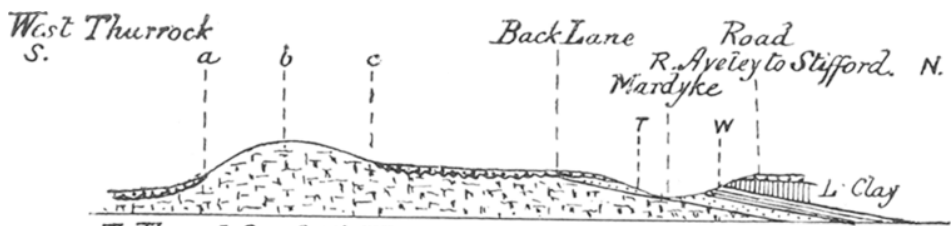

$T=$ Thanet Sard. W = Woolwich Beds. Length of Section 2 niles.

Fig. 2.-Section along the Grays and Upminster Railway from West Thurrock to The N. Side of the Mardyke.- $T$. $V$. Holmes.

difficult to imagine any explanation of the confused junction of the London Clay with the gravel north of the Mardyke which could wholly exclude ice action, because in that instance piping would be powerless. At the same time it must be remembered that a river undermining a clay cliff would be certain to receive from it, from time to time, lumps of clay, which, falling upon gravel and sand in the channel of the stream, would contort the material on which they fell.

The power of river-ice to produce results recognised as glacial -which are sometimes rashly supposed to be inseparably connected with the Glacial Period-was demonstrated at the meeting on March 6th, by Mr. Atkinson, when he exhibited glacially scratched chalk from the foreshore of the Thames at Chelsea, the work of blocks of river-ice during the winter I 890-9 I.

Another point of interest in this gravel is the occurrence in it of hollows, the work of natural agencies, formed immediately beneath hard bands which have been compacted together by a ferruginous cement. Consequently, when the less coherent material below has descended into a pipe in the Chalk, the hard 
band has remained firm, and a hollow has been formed beneath it. The largest cavity I saw was about $3 \mathrm{ft}$. long, and 9 or Io inches high, its axis being nearly horizontal. For accounts of similarly formed hollows I may refer to my " Notes on the Oldhaven Pebble Beds at Caterham" (Proc. Geol. Assoc., vol. ix., p. I05, August, I 885).

On arrival at Grays the party proceeded towards West Thurrock, noting the many extensive chalk pits on their right, a little northward of the road, where the flat of valley gravel they were traversing joined higher ground. On turning northward to walk along the new line, they stayed for a minute or two at the point (a). The junction of the Valley Gravel with the Chalk was not so clear as could have been wished, though perfectly perceptible. The Chalk northward of this point had been cut to its full

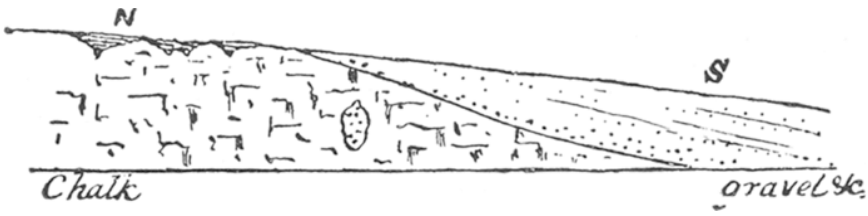

Fig 3. Diagram Section at $a,-T, V$. Holmes.

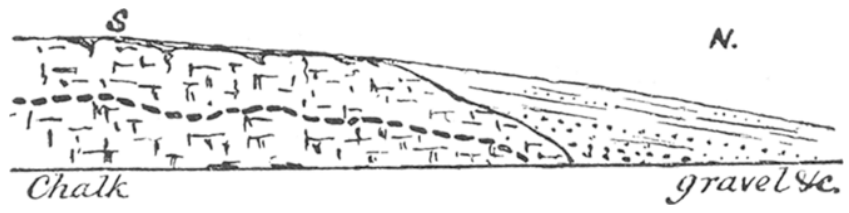

Fig. 4. Diagram Section at c.-T. V. Holmes

depth, and presented a vertical wall on each side of the line, 25 feet or more in height. The most noticeable feature in the appearance of the Chalk was a peculiar light green tint with which a large proportion of the surface was covered, apparently the result of the growth of a lichen. A galerite was found, and some decomposed nodules of iron-pyrites were seen. Towards the northern end of the cutting, at $(c)$, the curiously wavy course taken by a well-marked flint-band attracted much attention. Its general dip was evidently northward. When the cutting between $(a)$ and (c) was first made this band was visible for a considerable distance south of $(c)$, its general dip remaining unchanged.

At the northern end of the cutting the junction of the Chalk with gravel, \&c., of a higher level than that near West Thurrock was also more obscure that it had been on previous occasions, and thence to the Mardyke scarcely anything could be seen in 
consequence of the sloping of the sides of the cutting, and the growth of vegetation on the slopes. Owing to this cause, the singularly confused junction between the Chalk and this gravel, near but south of Back Lane, was quite invisible, while the gravel itself could be seen only at one spot, for a horizontal distance of perhaps a dozen yards. But a photograph taken by Mr. A. P. Wire, Librarian to the Essex Field Club, was exhibited and showed to members the appearances formerly seen. The junction of the Chalk with the Thanet Sand, and the latter formation itself thence to the Mardyke Valley were also imperceptible beneath the green slopes. But on crossing the Mardyke, and passing under the bridge by means of which the Aveley and Stifford Road crosses the line, a much better section than the Director had seen on previous visits was revealed. It showed a remarkably confused junction between the London Clay and the overlying sand and gravel, a junction comparable, in the mixed-up state of things presented, to that once visible on the southern side of Back Lane: For $15^{\circ}$ or 200 yards north of the Aveley and Stifford Road the sections showed but little gravel and sand above the London Clay, but about halfway between the Aveley Road and the footpath which crosses the new railway and touches the South Ockendon Road a little south of Buckles Farm, the gravel and sand were found to thicken, and the London Clay ceased to be visible even in a cutting 10 or 12 feet deep. On reaching the footpath just mentioned it was decided to return to Grays through Stifford.

As regarded the Thames Valley Gravel near West Thurrock, the Director remarked that it would be seen that the highest point which it reached was the 50 feet contour line, the mass of it being much below that level. On the other hand, the gravel and sand north of the Chalk cutting formed the surface of a plateau from $6 \circ$ to $7 \circ \mathrm{ft}$. above Ordnance Datum. They would notice, looking from Back Lane southward, how flattened in contour was the ground occupied by this gravel, and how easily it could be distinguished from the higher ground behind it formed by the Tertiary outlier. At the same time they would not find it easy to map the limits of the two with accuracy. On crossing the Mardyke they would see that the gravel and sand overlying the London Clay along the greater part of the new line, almost to Upminster, formed a flat-topped plateau similar in every way to that before them, and corresponding to it in height. The gravel north and south of the Mardyke was, in short, part of the same sheet, though now separated by that sluggish stream. It had no doubt been formed when the Thames both flowed at a higher level, and had a channel northward of that which it occupied when the gravel near West Thurrock was deposited. For ages the Thames, as shown by the broad spreads of old river gravel in South Essex, had been, on the whole, cutting its way southward.

Stifford is a parish known by name to many not otherwise 
acquainted with it, as that treated of by Palin in the two volumes entitled : "Stifford," and "More about Stifford." On approaching Chalk Pit Farm, called "Sugar-loaf House" on the old one-inch Ordnance Map, the Director called attention to a spot in the road a few yards north of the house at which a subsidence had suddenly occurred in August, 1888. About onethird of a mile nearer Grays the party halted to see the spot at which another subsidence had occurred in May, r889. Some account of these subsidences is given in the Essex Naturalist, July to September, 1889 (vol. iii., p. I83). The Director remarked that he had inspected the one before them (which had been partly filled up by old pots and pans) soon after it revealed itself. At the bottom of the shaft were irregular workings in the Chalk, such as were common in country where chalk might be obtained for marling land at a depth of 5,10 , or $20 \mathrm{ft}$. As they had seen in the Grays and other chalk pits, the surface, where there was no definite formation above the Chalk, might yet consist largely of clay with flints, \&c., so that the amount of chalk obtainable in a shallow open pit might be by no means great. In order, therefore, to secure pure chalk, a shaft was sunk a few feet below the surface, as much chalk as might be required removed, and the workings allowed to tumble in so as to form a shallow hollow such as might result from an open pit, but with the advantage that chalk only was obtained, and not a variable mixture of chalk and other material. In the case before them, however, it would appear that sufficient chalk having been removed, rubbish had been thrown down the shaft. On this faggots had been hurled, which had been covered at the surface with earth well trodden in, so that there was no sign of the existence of the pit below. But the faggots would slowly rot away, while the earth above them remained hard and tight, till some event, such as an unusually heavy fall of rain, or the passage of a huge waggon over the spot, caused a sudden subsidence. Pits like that before them were quite distinct in character from the great collection in Harigman's Wood about a mile away, inasmuch as the makers of the lattersupposing them for the sake of argument to have wanted chalk as their primary object-deliberately concentrated their efforts to get it where they obtained the least return for their exertions, though there was evidently plenty of bare chalk within a mile. The top of the Chalk in Hangman's Wood is between 50 and $60 \mathrm{ft}$. below the surface.

As regarded the section at the subsidence they were looking at, it consisted of:

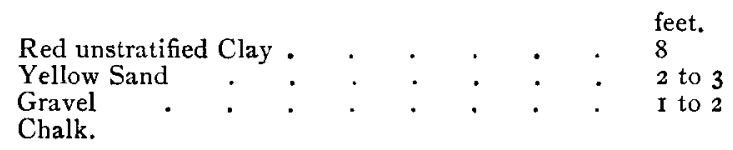


This section resembled nothing that might naturally be expected to rest on the Chalk in this district. It was in all probability material deposited in the bed of a stream which had once flowed over the Chalk. In the great chalk pit west of the Grays and Stifford Road, which had been visited the week before, many members had noticed, at the northern end of the pit, evidence of a channel scooped out of the Thanet Sand. The material seen at the subsidence had probably filled a northerly continuation of this channel, which might have been that of a representative of the Mardyke, flowing at a higher level than the present stream, and preserving between Stifford and Grays the same direction it had above Stifford, instead of making a westerly turn there so as to join the Thames at Purfleet, as did the modern stream.

It is noticeable that the position of the workings disclosed by this subsidence, or rather subsidences (for there are two hollows 9 or to feet apart giving admission to one set of workings), is very close to the Grays and Stifford Road. They are visible on the western side of this road, at a point where the boundary line between the parishes of Grays and Stifford comes to the road from the east, and takes a southerly course along it. Old chalk pits exist within a few yards both of this subsidence and of that nearer Stifford. These chalk pits are now disused, and have been so for many years, though the largest, which is between the two places at which these subsidences have occurred, covers many acres of ground, and is marked on an old map of Essex, by John Chapman and Peter André, dating from 1 77 2-73-74. As these workings at the subsidences are not likely to have been made while the surrounding chalk pits were in use, and as the large chalk pit mentioned must have been begun many years-perhaps a century or more - before $\mathbf{1 7 7 2}$, when it had attained a considerable size, they must be, in all probability, older than the open chalk pits. But though there can be little doubt that they were made some centuries ago, nothing was found to give any clue to their approximate age, the pick marks visible here and there presenting no peculiarity, and the floor having been covered from their first appearance by a mass of fallen material.

After tea at the King's Arms Hotel, Grays, the party returned to London by the 8.22 train.

\section{REFERENCES.}

Geological Survey Map, Sheet I, S.W. (Drift Edition).

New Ordnance Survey Map, Sheet 27r.

I889. Whitaker, W._-"The Geology of London," Mem. Geol. Survey.

I89o. Holmes, T. V.- "Some Sections between West Thurrock and Stifford, \&c.," Essex Naturalist, vol. iv., pp. 143-149.

[From the latter paper the illustrations accompanying this Report have been kindly lent by the Essex Field Club.] 